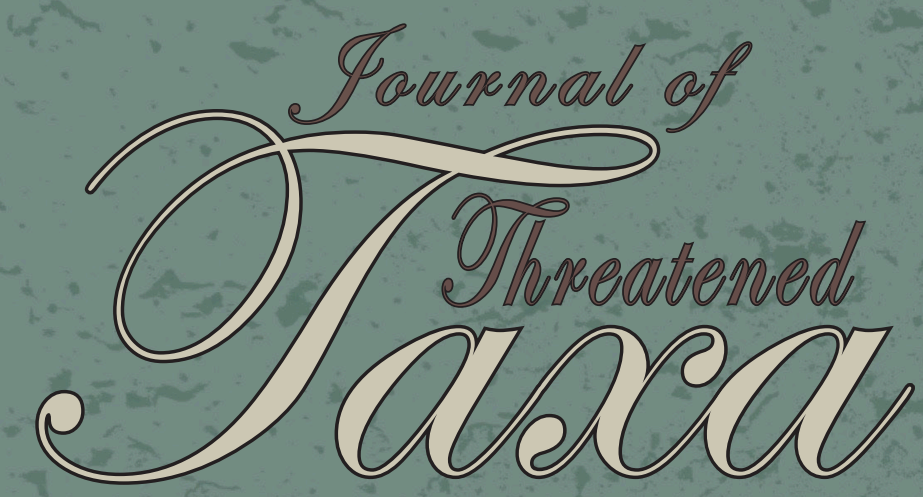

Building evidence for conservation globally
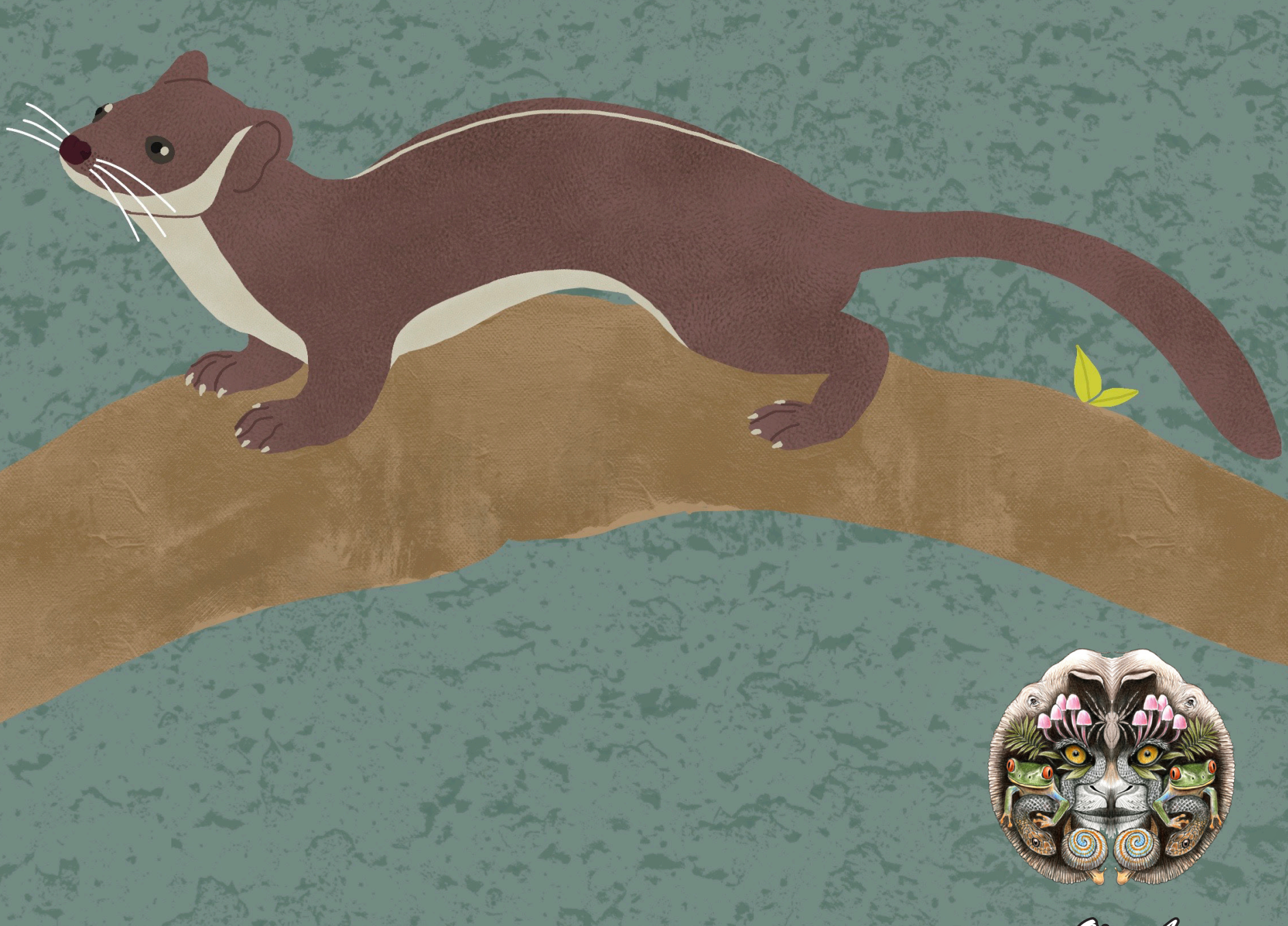

Qpecosecess

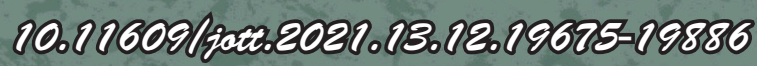
cocosurthreatecredtassararg

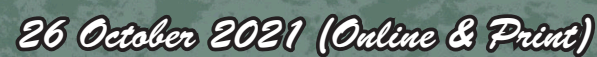

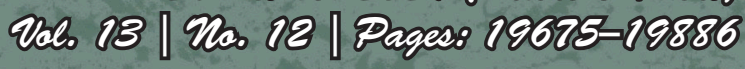




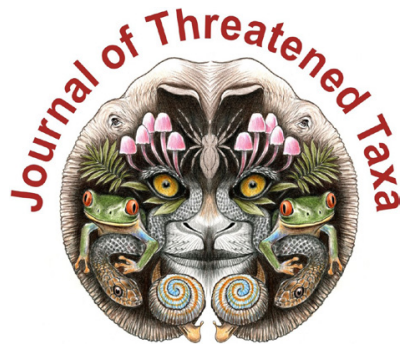

ISSN 0974-7907 (Online); ISSN $0974-7893$ (Print)

Publisher

Host

Wildlife Information Liaison Development Society

www.wild.zooreach.org

Zoo Outreach Organization www.zooreach.org

No. 12, Thiruvannamalai Nagar, Saravanampatti - Kalapatti Road, Saravanampatti, Coimbatore, Tamil Nadu 641035, India

Ph: +91 9385339863 | www.threatenedtaxa.org

Email: sanjay@threatenedtaxa.org

EDITORS

\section{Founder \& Chief Editor}

Dr. Sanjay Molur

Wildlife Information Liaison Development (WILD) Society \& Zoo Outreach Organization (ZOO)

12 Thiruvannamalai Nagar, Saravanampatti, Coimbatore, Tamil Nadu 641035, India

\section{Deputy Chief Edito}

Dr. Neelesh Dahanukar

Noida, Uttar Pradesh, India

\section{Managing Editor}

Mr. B. Ravichandran, WILD/ZOO, Coimbatore, India

\section{Associate Editors}

Dr. Mandar Paingankar, Government Science College Gadchiroli, Maharashtra 442605, India Dr. Ulrike Streicher, Wildlife Veterinarian, Eugene, Oregon, USA

Ms. Priyanka Iyer, ZOO/WILD, Coimbatore, Tamil Nadu 641035, India

Dr. B. A. Daniel, $200 /$ WIID, Coimbatore, Tamil Nadu 641035, India

\section{Editorial Board}

Dr. Russel Mittermeie

Executive Vice Chair, Conservation International, Arlington, Virginia 22202, USA

\section{Prof. Mewa Singh Ph.D., FASc, FNA, FNASc, FNAPsy}

Ramanna Fellow and Life-Long Distinguished Professor, Biopsychology Laboratory, and Institute of Excellence, University of Mysore, Mysuru, Karnataka 570006, India; Honorary Professor, Jawaharlal Nehru Centre for Advanced Scientific Research, Bangalore; and Adjunct Professor, National Institute of Advanced Studies, Bangalore

\section{Stephen D. Nash}

Scientific Illustrator, Conservation International, Dept. of Anatomical Sciences, Health Sciences Center, T-8, Room 045, Stony Brook University, Stony Brook, NY 11794-8081, USA

\section{Dr. Fred Pluthero}

Toronto, Canada

\section{Dr. Priya Davidar}

Sigur Nature Trust, Chadapatti, Mavinhalla PO, Nilgiris, Tamil Nadu 643223, India

\section{Dr. Martin Fisher}

Senior Associate Professor, Battcock Centre for Experimental Astrophysics, Cavendish

Laboratory, JJ Thomson Avenue, Cambridge CB3 OHE, UK

\section{Dr. John Fellowes}

Honorary Assistant Professor, The Kadoorie Institute, 8/F, T.T. Tsui Building, The University of Hong Kong, Pokfulam Road, Hong Kong

\section{Prof. Dr. Mirco Solé}

Universidade Estadual de Santa Cruz, Departamento de Ciências Biológicas, Vice-coordenado do Programa de Pós-Graduação em Zoologia, Rodovia Ilhéus/Itabuna, Km 16 (45662-000)

Salobrinho, Ilhéus - Bahia - Brasil

\section{Dr. Rajeev Raghavan}

Professor of Taxonomy, Kerala University of Fisheries \& Ocean Studies, Kochi, Kerala, India

\section{English Editors}

Mrs. Mira Bhojwani, Pune, India

Dr. Fred Pluthero, Toronto, Canad

Mr. P. Ilangovan, Chennai, India

Web Maintenance

Mrs. Latha G. Ravikumar, ZOO/WILD, Coimbatore, India

\section{Typesetting}

Mr. Arul Jagadish, ZOO, Coimbatore, India

Mrs. Radhika, ZOO, Coimbatore, India

Mrs. Geetha, ZOO, Coimbatore India

\section{Fundraising/Communications}

Mrs. Payal B. Molur, Coimbatore, India

Subject Editors 2018-2020

Fungi

Dr. B. Shivaraju, Bengaluru, Karnataka, India

Dr. R.K. Verma, Tropical Forest Research Institute, Jabalpur, India

Dr. Vatsavaya S. Raju, Kakatiay University, Warangal, Andhra Pradesh, India

Dr. M. Krishnappa, Jnana Sahyadri, Kuvempu University, Shimoga, Karnataka, India

Dr. K.R. Sridhar, Mangalore University, Mangalagangotri, Mangalore, Karnataka, India

Dr. Gunjan Biswas, Vidyasagar University, Midnapore, West Bengal, India

Plants

Dr. G.P. Sinha, Botanical Survey of India, Allahabad, India

Dr. N.P. Balakrishnan, Ret. Joint Director, BSI, Coimbatore, India

Dr. Shonil Bhagwat, Open University and University of Oxford, UK

Prof. D.J. Bhat, Retd. Professor, Goa University, Goa, India

Dr. Ferdinando Boero, Università del Salento, Lecce, Italy

Dr. Dale R. Calder, Royal Ontaro Museum, Toronto, Ontario, Canada

Dr. Cleofas Cervancia, Univ. of Philippines Los Baños College Laguna, Philippines

Dr. F.B. Vincent Florens, University of Mauritius, Mauritius

Dr. Merlin Franco, Curtin University, Malaysia

Dr. V. Irudayaraj, St. Xavier's College, Palayamkottai, Tamil Nadu, India

Dr. B.S. Kholia, Botanical Survey of India, Gangtok, Sikkim, India

Dr. Pankaj Kumar, Kadoorie Farm and Botanic Garden Corporation, Hong Kong S.A.R., China

Dr. V. Sampath Kumar, Botanical Survey of India, Howrah, West Bengal, India

Dr. A.J. Solomon Raju, Andhra University, Visakhapatnam, India

Dr. Vijayasankar Raman, University of Mississippi, USA

Dr. B. Ravi Prasad Rao, Sri Krishnadevaraya University, Anantpur, India

Dr. K. Ravikumar, FRLHT, Bengaluru, Karnataka, India

Dr. Aparna Watve, Pune, Maharashtra, India

Dr. Qiang Liu, Xishuangbanna Tropical Botanical Garden, Yunnan, China

Dr. Noor Azhar Mohamed Shazili, Universiti Malaysia Terengganu, Kuala Terengganu, Malaysia Dr. M.K. Vasudeva Rao, Shiv Ranjani Housing Society, Pune, Maharashtra, India

Prof. A.J. Solomon Raju, Andhra University, Visakhapatnam, India

Dr. Mandar Datar, Agharkar Research Institute, Pune, Maharashtra, India

Dr. M.K. Janarthanam, Goa University, Goa, India

Dr. K. Karthigeyan, Botanical Survey of India, India

Dr. Errol Vela, University of Montpellier, Montpellier, France

Dr. P. Lakshminarasimhan, Botanical Survey of India, Howrah, India

Dr. Larry R. Noblick, Montgomery Botanical Center, Miami, USA

Dr. K. Haridasan, Pallavur, Palakkad District, Kerala, India

Dr. Analinda Manila-Fajard, University of the Philippines Los Banos, Laguna, Philippines

Dr. P.A. Sinu, Central University of Kerala, Kasaragod, Kerala, India

Dr. Afroz Alam, Banasthali Vidyapith (accredited A grade by NAAC), Rajasthan, India

Dr. K.P. Rajesh, Zamorin's Guruvayurappan College, GA College PO, Kozhikode, Kerala, India

Dr. David E. Boufford, Harvard University Herbaria, Cambridge, MA 02138-2020, USA

Dr. Ritesh Kumar Choudhary, Agharkar Research Institute, Pune, Maharashtra, India

Dr. Navendu Page, Wildlife Institute of India, Chandrabani, Dehradun, Uttarakhand, India

Invertebrates

Dr. R.K. Avasthi, Rohtak University, Haryana, India

Dr. D.B. Bastawade, Maharashtra, India

Dr. Partha Pratim Bhattacharjee, Tripura University, Suryamaninagar, India

Dr. Kailash Chandra, Zoological Survey of India, Jabalpur, Madhya Pradesh, India

Dr. Ansie Dippenaar-Schoeman, University of Pretoria, Queenswood, South Africa

Dr. Rory Dow, National Museum of natural History Naturalis, The Netherlands

Dr. Brian Fisher, California Academy of Sciences, USA

Dr. Richard Gallon, llandudno, North Wales, LL30 1UP

Dr. Hemant V. Ghate, Modern College, Pune, India

Dr. M. Monwar Hossain, Jahangirnagar University, Dhaka, Bangladesh

Mr. Jatishwor Singh Irungbam, Biology Centre CAS, Branišovská, Czech Republic.

Dr. lan J. Kitching, Natural History Museum, Cromwell Road, UK

Dr. George Mathew, Kerala Forest Research Institute, Peechi, India

Dr. John Noyes, Natural History Museum, London, UK

For Focus, Scope, Aims, and Policies, visit https://threatenedtaxa.org/index.php/JoTT/aims_scope
For Article Submission Guidelines, visit https://threatenedtaxa.org/index.php/JoTT/about/submissions
For Policies against Scientific Misconduct, visit https://threatenedtaxa.org/index.php/JoTT/policies_various

continued on the back inside cover 


\title{
Is release of rehabilitated wildlife with embedded lead ammunition advisable? Plumbism in a Jaguar Panthera Onca (Mammalia: Carnivora: Felidae), survivor of gunshot wounds
}

\author{
Eduardo A. Díaz ${ }^{1}$ (D), Carolina Sáenz ${ }^{2}$ (D) E. Santiago Jiménez ${ }^{3}$ (D), David A. Egas ${ }^{4}$ (D) \& Kelly Swing ${ }^{5}$ (D) \\ ${ }^{1}$ Universidad San Francisco de Quito, Colegio de Ciencias de la Salud, Escuela de Medicina Veterinaria, Diego de Robles s/n, \\ Quito 170901, Ecuador. \\ 1,2 Universidad San Francisco de Quito, Hospital de Fauna Silvestre TUERI, Diego de Robles s/n, Quito 170901, Ecuador. \\ 3,4 Universidad San Francisco de Quito, Colegio de Ciencias e Ingeniería, Departamento de Ingeniería Química, Diego de Robles s/n, \\ Quito 170901, Ecuador. \\ ${ }^{5}$ Universidad San Francisco de Quito, Colegio de Ciencias Biológicas y Ambientales, Estación de Biodiversidad Tiputini, Diego de Robles \\ $\mathrm{s} / \mathrm{n}$, Quito 170901, Ecuador \\ ${ }^{1}$ eadiaz@usfq.edu.ec (corresponding author), ’2csaenz@usfq.edu.ec, ${ }^{3}$ eder.jimenez@estud.usfq.edu.ec, ${ }^{4}$ degas@usfq.edu.ec, \\ ${ }^{5}$ kswing@usfq.edu.ec
}

\begin{abstract}
Lead poisoning is a threat to wildlife, particularly afte ingestion of lead ammunition derived from hunting activities. Little information, however, is available concerning plumbism in wild animals that survive the trauma associated with gunshot wounds. This study presents a possible example of lead intoxication by embedded pellets in a Jaguar Panthera onca nineteen months after being injured by a shotgun blast. In addition, the possible path of incorporation of lead into the trophic chain after the eventual release and death of an impacted animal, thereby expanding and prolonging the toxic effects of lead ammunition, is discussed. Direct intoxication by ammunition retained in the body of wild animals, as well as the indirect impacts on predators and scavengers that consume their flesh, should be sufficient reasons to reconsider the release of individuals with embedded lead ammunition into the wild.
\end{abstract}

Keywords: Blood lead levels, endangered species, lead-free ammunition, trophic web.
The Jaguar Panthera onca, is the largest American felid, and the only living representative of the genus Panthera in the New World (Caragiulo et al. 2016). Historically distributed from the southwestern United States to southern Argentina, Jaguars inhabit a wide range of ecological zones, from tropical moist forests, to xeric shrublands, to tropical dry forests, to grasslands and savannas (Sanderson et al. 2002). The IUCN Red List classifies the species globally as Near Threatened since 2002; the population trend is decreasing due to habitat loss and direct human persecution (Quigley et al. 2017). Currently, although the species is included in Appendix I of the Convention on International Trade in Endangered Species (CITES 2019), threats have continued or intensified at local and regional scales, and Jaguars have already disappeared from $55 \%$ of their historical range. The majority of subpopulations are Endangered

Citation: Díaz, E.A., C. Sáenz, E.S. Jiménez, D.A. Egas \& K. Swing(2021). Is release of rehabilitated wildlife with embedded lead ammunition advisable? Plumbism in a Jaguar Panthera Onca (Mammalia: Carnivora: Felidae), survivor of gunshot wounds. Journal of Threatened Taxa 13(12): 19808-19812. https://doi.org/10.11609/ jott.5777.13.12.19808-19812

Copyright: (c) Díaz et al. 2021. Creative Commons Attribution 4.0 International License. JoTT allows unrestricted use, reproduction, and distribution of this article in any medium by providing adequate credit to the author(s) and the source of publication.

Funding: Publication of this article was funded by the Universidad San Francisco de Quito Research Publication Fund.

Competing interests: The authors declare no competing interests.

Acknowledgements: The authors thank the Ministerio del Ambiente, Inmobiliar, Unidad de Protección del Medio Ambiente and the Tiputini Biodiversity Station for supporting this research. This study was conducted under official agreement and permit issued by Ecuador's Ministry of the Environment (permit 019-2018-ICFAU-DNB/MAE) and authorized by the animal ethics committee of Universidad San Francisco de Quito (permit 2018-011). Publication of this article was funded by the Universidad San Francisco de Quito Research Publication Fund. 
or Critically Endangered (De la Torre et al. 2018). In Ecuador, where hunting remains one of the main threats to the species, two subspecies are separated by the Andean highlands, the Endangered Panthera onca onca from Amazon rainforest (Espinosa et al. 2011a), and the Critically Endangered $P$. onca centralis from the western coast (Espinosa et al. 2011b).

Lead ammunition is highly toxic for wildlife, especially in long-lived scavengers and predators (Gil-Sánchez et al. 2018). Intoxication of wildlife following ingestion of lead ammunition has long been recognized (Pain et al. 2019), contributing to population decline of some threatened species (Fernandez et al. 2011; Finkelstein et al. 2012; Garbett et al. 2018). Nonetheless, little is known about the impact of retained lead projectiles from gunshot wounds, despite a high incidence of embedded lead in wild animals secondary to hunting injuries (LaDoucer et al. 2015, Berny et al. 2017). This study describes lead poisoning through retained ammunition in an Endangered Amazon Jaguar subsequent to its recovery from multiple firearm injuries, and the possible incorporation of lead into the trophic chain after incidental ingestion by scavengers.

\section{MATERIAL AND MethodS}

On 31 October 2016, a juvenile female Jaguar was transferred from the province of Sucumbíos in northeastern Ecuador to the Wildlife Hospital TUERI of Universidad San Francisco de Quito (USFQ) for evaluation of injuries caused by a shotgun blast. Radiographic series (Sharp Ray LWX-20P) revealed the presence of 18 pellets scattered dorso-anteriorly; six of these were removed surgically (Image 1). The patient gradually improved and was transferred to the recovery center to complete the rehabilitation process two months after admission. In the following nine months, the Jaguar exhibited natural behaviors in terms of hunting and fishing, as well as aversion to and flight from human presence, which indicated excellent potential for successful release into the wild. Eleven months after her original injuries, the Jaguar was captured from its enclosure for clinical evaluation and to assess the possible reabsorption of embedded lead; blood lead levels (BLL) were measured by atomic absorption spectrophotometry (Buck Scientific 210VGP).

Showing no indications of complicating factors, the patient was clinically discharged but still held in
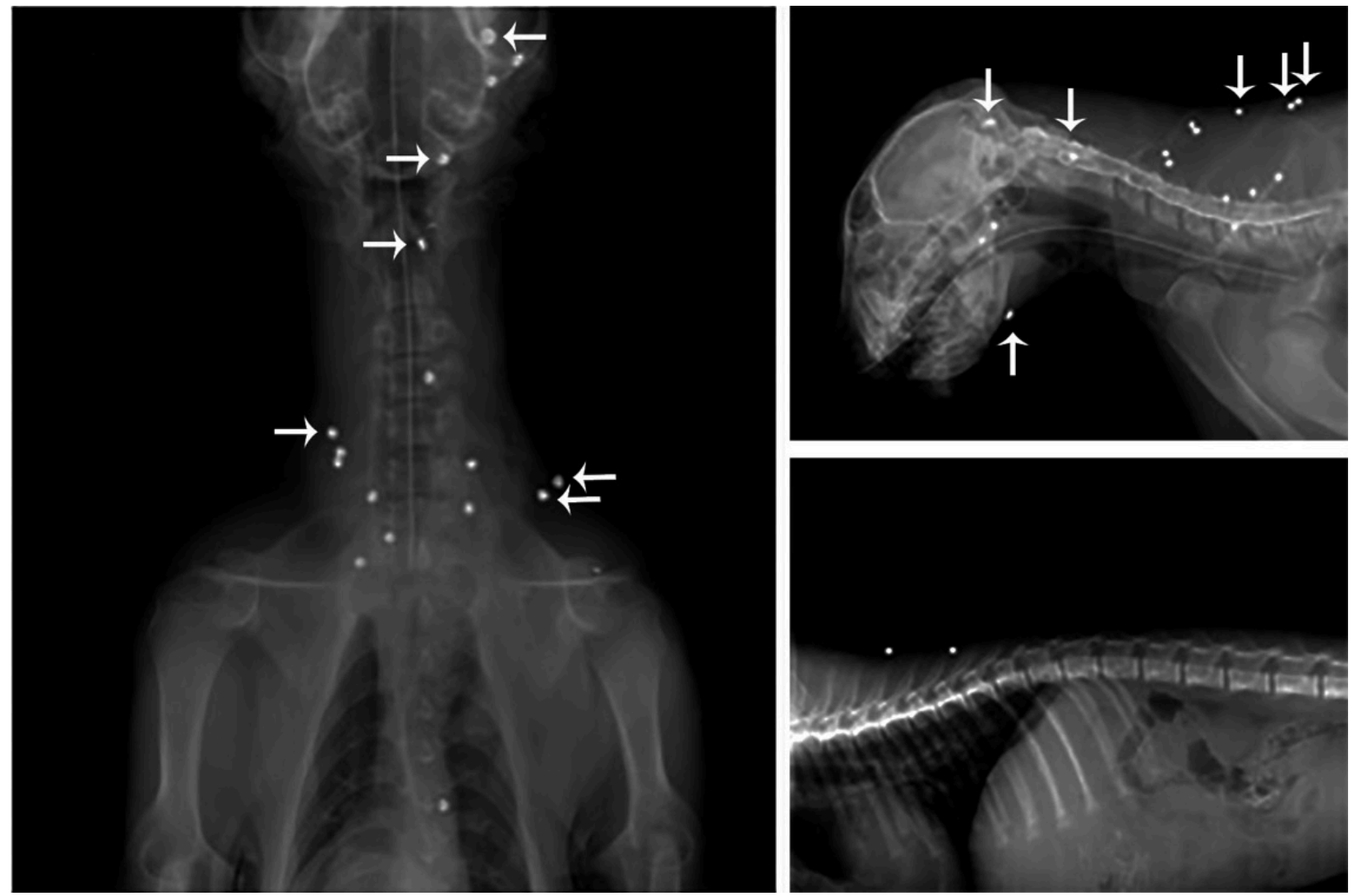

Image 1. Radiographs showing the presence of 18 lead pellets scattered dorso-anteriorly in a juvenile female Jaguar. Arrows indicate the six pellets removed surgically. 
natural-setting captivity while her eventual release into a remote area of Yasuní Biosphere Reserve was planned. In the following eight months, she was captured twice more, specifically for the placement of a satellite collar (Telonics TGW-4577-4) for post-release monitoring, and ultimately to evaluate her overall condition for transfer to the release site. Following release on 21 May 2018, the Jaguar was tracked for four days after which the satellite device stopped transmitting movements; the animal was found dead four days later. The carcass presented an advanced state of decomposition and was being scavenged by vultures at the time of encounter. Remains were transferred to Wildlife Hospital TUERI for forensic analysis, including radiology (Sharp Ray LWX-20P) and scanning electron microscopy (JEOL JSMIT300LA) of bones. Blood samples collected on the day of release were analyzed post-mortem by atomic absorption spectrophotometry (Buck Scientific 210VGP) to determine the possible reabsorption of embedded lead into general circulation.

\section{RESULTS}

As previously mentioned, after surgery, twelve lead pellets remained embedded in the Jaguar's body; none within the digestive system or skeletal articulations (Image 1), sites classically considered to present elevated risks (Eward et al. 2011). Eleven months later, no clinical symptoms of lead intoxication were identified, and BLL measurement was negative to the sensitivity limit $0.001 \mu \mathrm{g} / \mathrm{dl}$. After release, satellite tracking showed movement for four days - 2.7, 1.5, 1.2, and $0.3 \mathrm{~km} /$ day, respectively. The advanced state of decomposition presented by the carcass when located only allowed radiological examination; no superficial evidence of the cause of death could be ascertained due to the putrefied condition of the body. None of the 12 pellets remaining in the animal's body were detected by radiographic series. Scanning electron microscopy showed no traces of lead in the bone samples. Atomic absorption spectrophotometry analysis of blood samples collected on the day of the release revealed high BLL $(1,223 \mu \mathrm{g} / \mathrm{dl})$ in noteworthy contrast to earlier samples.

\section{Discussion}

Embedded lead has been identified as a risk factor causing plumbism in humans and experimental animals, but it has been poorly investigated in wildlife (LaDoucer et al. 2015; Berny et al. 2017). According to our knowledge, there are no data that relate the presence of embedded projectiles with BLL in wild mammals, but in humans, values greater than $25-40 \mu \mathrm{g} / \mathrm{dL}$ can cause symptoms that range from quite mild to coma and death (Bustamante \& Macias-Konstantopoulos 2016). In the present study, no obvious outward symptoms were identified during the time that the Jaguar remained in captivity. Nevertheless, although BLL were not detected during the first eleven months, eight months later they reached one of the highest values recorded to date for a wild felid (Burco et al. 2012; North et al. 2015). This could be due to the type of exposure. In the case of chronic exposure, symptoms appear progressively and become incrementally more severe as time passes. Conversely, severe symptoms can erupt suddenly in acute exposures (Kim et al. 2015). Therefore, absence of evident clinical symptoms, and sudden death of the Jaguar, may have been due to acute absorption of lead.

Pain, weakened muscle strength, sensory abnormalities and brain inflammation can appear as acute symptoms in plumbism. More severe manifestations occur at very concentrated exposures, and symptoms abruptly worsen to include delirium, loss of muscular coordination, convulsions, ataxia, paralysis, coma and death (Sanders et al. 2009; Flora et al. 2012). Following release, satellite tracking revealed that the distance moved by the animal progressively decreased in the subsequent days $(2.7,1.5,1.2$, and $0.3 \mathrm{~km} /$ day).

In an effort to corroborate the hypothesis of acute exposure, a bone analysis was performed seeking to determine the presence of lead. The accumulation of lead in bones is indicative of long-term exposure due to its extended residence time, in contrast to BLL that is used to measure recent exposure because of the short half-life of lead in the blood (Green \& Pain 2019). Scanning electron microscopy did not detect lead residues in bone samples, confirming that the embedded reabsorption would not have been chronic.

In most cases of plumbism, lead is ingested and absorbed into the bloodstream through the intestinal tract. Acute onset of nervous symptoms is a potential condition of captive felids fed hunted game animals (North et al. 2015). In our case, the Jaguar did not receive hunted meat or any other type of food that could contain traces of lead, making it is impossible that the poisoning occurred in this way; any BLL should come through reabsorption from the ammunition embedded in its body. In human cases, lead toxicity with intraarticular retained ammunition is indeed considered a risk, but extra-articular embedded lead, when difficult to extract, is routinely permitted to remain in tissues indefinitely without surveillance for lead toxicity. However, lead toxicity associated with extra-articular retained ammunition, although uncommon, may be 
asymptomatic and difficult to diagnose yet debilitating and potentially lethal (Eward et al. 2011; Grasso et al. 2017). This fact could corroborate our findings in the present case. Although there seems to be no clear relationship between the amount of lead retained, residence time or location in the human body, embedded lead cannot be considered inert or safe (De Araújo et al. 2015).

Primary treatment in cases of retained lead ammunition usually includes chelation, followed by complete surgical removal of retained projectiles, in order to prevent systemic toxicity (Bustamante \& MaciasKonstantopoulos 2016). Nevertheless, sometimes the elimination of projectiles would require complicated surgical approach resulting in extensive tissue dissection and high morbidity in a patient weakened by trauma (De Araújo et al. 2015). When surgical removal of ammunition fragments is contra-indicated, there are currently no long-term treatment methods available, since the source of exposure remains in the body, and prolonged chelation would cause adverse health effects such as hepatotoxicity or nephrotoxicity (McQuirter et al. 2004; Flora \& Pachauri 2010). Therefore, these patients should be considered at chronic risk for lead poisoning and monitored periodically (Moazeni et al. 2014).

Finally, in the radiological tests performed on the Jaguar carcass, none of the 12 embedded pellets was detected. A likely explanation is incidental ingestion by scavengers; three species of vultures were identified next to the Jaguar cadaver: the American Black Vulture Coragyps atratus, the Greater Yellow-headed Vulture Cathartes melambrotus, and the King Vulture Sarcoramphus papa. Therefore, lead projectiles retained in the Jaguar's body could have had devastating effects not only for the Jaguar itself, but also for other species upon entering the trophic web through carrion consumers. In South America, with lead poisoning being a major widespread conservation threat for the Andean Condor Vultur gryphus (and probably for other sympatric carnivores also), urgent conservation actions to reduce this toxin in the wild are necessary (Wiemeyer et al. 2017). In this sense, evidence on the adverse effects of the use of lead ammunition on wildlife is ample. Because the change to non-toxic alternatives is possible and would allow important benefits for nature conservation (Kanstrup et al. 2018; Cromie et al. 2019), the strategy should be considered and implemented on a much broader scale.

In conclusion, some limitations of this work have been the lack of more thorough BLL monitoring during the time that the patient remained in captivity due to the difficult handling of the species, and the impossibility of assessing the presence of lead in other soft tissues after death because of the advanced state of decomposition in which the carcass was found. According to the authors' knowledge, the present study suggests for the first time that the presence of embedded pellets can be associated with a significant blood lead concentration in a wild felid. This situation reinforces the need for better understanding of the toxic effects of lead in wildlife surviving gunshot wounds. Until then, each patient with lead ammunition retained in its body should be considered at chronic risk for itself and a potential danger to other species that may eventually feed on it. Therefore, release of individuals with embedded lead projectiles should be carefully considered by wildlife managers when complete removal of lead fragments is not possible.

\section{REFERENCES}

Berny, P.J., E. Mas \& D. Vey (2017). Embedded lead shots in birds of prey: the hidden threat. European Journal of Wildlife Research 63(6): 101. https://doi.org/10.1007/s10344-017-1160-z

Burco, J., A.M. Myers, K. Schuler \& C. Gillin (2012). Acute lead toxicosis via ingestion of spent ammunition in a free-ranging cougar (Puma concolor). Journal of Wildlife Diseases 48(1): 216-219. https://doi. org/10.7589/0090-3558-48.1.216

Bustamante, N.D. \& W.L. Macias-Konstantopoulos (2016). Retained lumbar bullet: a case report of chronic lead toxicity and review of the literature. Journal of Emergency Medicine 51(1): 45-49. https:// doi.org/10.1016/j.jemermed.2016.02.025

Caragiulo, A., E. Dougherty, S. Soto, S. Rabinowitz \& G. Amato (2016). The complete mitochondrial genome structure of the jaguar (Panthera onca). Mitochondrial DNA Part A 27(2): 914-915. https:// doi.org/10.3109/19401736.2014.926483

CITES (2019). Convention on International Trade in Endangered Species of Wild Fauna and Flora Appendices I, II and III. https://cites. org/sites/default/files/eng/app/2019/E-Appendices-2019-11-26. pdf. Downloaded on 30 November 2019.

Cromie, R., J. Newth \& E. Strong (2019). Transitioning to non-toxic ammunition: Making change happen. Ambio 48(9): 1079-1096. https://doi.org/10.1007/s13280-019-01204-y

De Araújo, G.C.S., N.T. Mourão, I.N. Pinheiro, A.R. Xavier \& V.S. Gameiro (2015). Lead toxicity risks in gunshot victims. PloS ONE 10(10): e0140220. https://doi.org/10.1371/journal.pone.0140220

De la Torre, J. A., J.F. González-Maya, H. Zarza, G. Ceballos \& R.A. Medellín (2018). The jaguar's spots are darker than they appear: assessing the global conservation status of the jaguar Panthera onca. Oryx 52(2): 300-315. https://doi.org/10.1017/ S0030605316001046

Espinosa, S., G. Zapata-Rios, M.A. Saavedra, J.J. Alava \& D.G. Tirira (2011a). Jaguar de la Amazonía (Panthera onca onca). In: Libro Rojo de los mamíferos del Ecuador (D.G. Tirira, ed.), 2a. edición. Fundación Mamíferos y Conservación, Pontificia Universidad Católica del Ecuador y Ministerio del Ambiente del Ecuador. Publicación especial sobre los mamíferos del Ecuador 8. Quito. 129-130.

Espinosa, S., G. Zapata-Rios, M.A. Saavedra, J.J. Alava \& D.G. Tirira (2011b). Jaguar de la Costa (Panthera onca centralis). In: Libro Rojo de los mamíferos del Ecuador (D. G. Tirira, ed.), 2a. edición. Fundación Mamíferos y Conservación, Pontificia Universidad Católica del Ecuador y Ministerio del Ambiente del Ecuador. Publicación especial sobre los mamíferos del Ecuador 8. Quito. 
94-95

Eward, W.C., D. Darcey, L.G. Dodd \& R.D. Zura (2011). Case report: lead toxicity associated with an extra-articular retained missile 14 years after injury. Journal of Surgical Orthopaedic Advances 20(4): 241.

Fernández, J.R.R., U. Höfle, R. Mateo, O.N. De Francisco, R. Abbott, P. Acevedo \& J.M. Blanco (2011). Assessment of lead exposure in Spanish imperial eagle (Aquila adalberti) from spent ammunition in central Spain. Ecotoxicology 20(4): 670-681. https://doi. org/10.1007/s10646-011-0607-3

Finkelstein, M.E., D.F. Doak, D. George, J. Burnett, J. Brandt, M. Church, J. Grantham \& D.R. Smith (2012). Lead poisoning and the deceptive recovery of the critically endangered California condor. Proceedings of the National Academy of Sciences 109(28): 11449-11454. https://doi.org/10.1073/pnas.1203141109

Flora, G., D. Gupta \& A. Tiwari (2012). Toxicity of lead: a review with recent updates. Interdisciplinary Toxicology 5(2): 47-58. https://doi. org/10.2478/v10102-012-0009-2

Flora, S.J. \& V. Pachauri (2010). Chelation in metal intoxication. International Journal of Environmental Research and Public Health 7(7): 2745-2788. https://doi.org/10.3390/ ijerph7072745

Garbett, R., G. Maude, P. Hancock, D. Kenny, R. Reading \& A. Amar (2018). Association between hunting and elevated blood lead levels in the critically endangered African White-backed Vulture Gyps africanus. Science of the Total Environment 630: 1654-1665. https://doi.org/10.1016/j.scitotenv.2018.02.220

Gil-Sánchez, J.M., S. Molleda, J.A. Sánchez-Zapata, J. Bautista, I. Navas, R. Godinho, A.J. García-Fernández \& M. Moleón (2018). From sport hunting to breeding success: Patterns of lead ammunition ingestion and its effects on an endangered raptor. Science of the Total Environment 613: 483-491. https://doi.org/10.1016/j. scitotenv.2017.09.069

Grasso, I.A., M.R. Blattner, T. Short \& J.W. Downs (2017). Severe systemic lead toxicity resulting from extra-articular retained shrapnel presenting as jaundice and hepatitis: a case report and review of the literature. Military Medicine 182(3-4): e1843-e1848. https://doi.org/10.7205/MILMED-D-16-00231

Green, R.E. \& J.D. Pain (2019). Risks to human health from ammunition-derived lead in Europe. Ambio 48(9): 954-968. https:// doi.org/10.1007/s13280-019-01194-x

Kanstrup, N., J. Swift, D.A. Stroud \& M. Lewis (2018). Hunting with lead ammunition is not sustainable: European perspectives. Ambio 47(8): 846-857. https://doi.org/10.1007/s13280-018-1042-y

Kim, H.C., T.W. Jang, H.J. Chae, W.J. Choi, M.N. Ha, B.J. Ye, B.G. Kim, M.J. Jeon, S.Y. Kim \& Y.S. Hong (2015). Evaluation and management of lead exposure. Annals of Occupational and Environmental Medicine 27(1): 30. https://doi.org/10.1186/s40557-015-0085-9

LaDouceur, E.E., R. Kagan, M. Scanlan \& T. Viner (2015). Chronically embedded lead projectiles in wildlife: a case series investigating the potential for lead toxicosis. Journal of Zoo and Wildlife Medicine 46(2): 438-442. https://doi.org/10.1638/2015-0026R.1

McBride, R.T. \& J.L. Thompson (2017). Space use and movement of jaguar (Panthera onca) in western Paraguay. Mammalia 82(6): 540549. https://doi.org/10.1515/mammalia-2017-0040

McQuirter, J.L., S.J. Rothenberg, G.A. Dinkins, V. Kondrashov, M. Manalo \& A.C. Todd (2004). Change in blood lead concentration up to 1 year after a gunshot wound with a retained bullet. American Journal of Epidemiology 159(7): 683-692. https://doi.org/10.1093/ aje/kwh074

Moazeni, M., F.M. Alibeigi, M. Sayadi, E.P. Mofrad, S. Kheiri \& M. Darvishi (2014). The serum lead level in patients with retained lead pellets. Archives of Trauma Research 3(2): e18950. https://doi. org/10.5812/atr.18950

Nascimento, C.R.B., W.E. Risso \& C.B. dos Reis Martinez (2016). Lead accumulation and metallothionein content in female rats of different ages and generations after daily intake of $\mathrm{Pb}$-contaminated food. Environmental Toxicology and Pharmacology 48: 272-277. https://doi.org/10.1016/j.etap.2016.11.001

North, M.A., E.P. Lane, K. Marnewick, P. Caldwell, G. Carlisle \& L.C. Hoffman (2015). Suspected lead poisoning in two captive cheetahs (Acinonyx jubatus jubatus) in South Africa, in 2008 and 2013. Journal of the South African Veterinary Association 86(1): 01-05. http://doi. org/10.4102/JSAVA.v86i1.1286

Pain, D.J., R. Mateo \& R.E. Green (2019). Effects of lead from ammunition on birds and other wildlife: A review and update. Ambio 48(9): 935-953. https://doi.org/10.1007/s13280-019-01159-0

Patrick, L. (2006). Lead Toxicity, a review of the literature. Part I: Exposure, Evaluation, and treatment. Alternative Medicine Review 11(1): 2-22.

Quigley, H., R. Foster, L. Petracca, E. Payan, R. Salom \& B. Harmsen (2017). Panthera onca (errata version published in 2018). The IUCN Red List of Threatened Species 2017: e.T15953A123791436. Downloaded 13 on November 2019. https:// doi.org/10.2305/IUCN.UK.2017-3.RLTS.T15953A50658693.en

Sanders, T., Y. Liu, V. Buchner \& P.B. Tchounwou (2009). Neurotoxic effects and biomarkers of lead exposure: a review. Reviews on Environmental Health 24(1): 15-46.

Sanderson, E.W., K.H. Redford, C.L.B. Chetkiewicz, R.A. Medellin, A.R. Rabinowitz, J.G. Robinson \& A.B. Taber (2002). Planning to save a species: the jaguar as a model. Conservation Biology 16(1): 58-72. https://doi.org/10.1046/j.1523-1739.2002.00352.x

Wiemeyer, G.M., M.A. Pérez, L.T. Bianchini, L. Sampietro, G.F. Bravo, N.L. Jácome, V. Astore \& S.A. Lambertucci (2017). Repeated conservation threats across the Americas: high levels of blood and bone lead in the Andean Condor widen the problem to a continental scale. Environmental Pollution 220: 672-679. https:// doi.org/10.1016/j.envpol.2016.10.025 

Dr. Albert G. Orr, Griffith University, Nathan, Australia

Dr. Sameer Padhye, Katholieke Universiteit Leuven, Belgium

Dr. Nancy van der Poorten, Toronto, Canada

Dr. Kareen Schnabel, NIWA, Wellington, New Zealand

Dr. R.M. Sharma, (Retd.) Scientist, Zoological Survey of India, Pune, India

Dr. Manju Siliwal, WILD, Coimbatore, Tamil Nadu, India

Dr. G.P. Sinha, Botanical Survey of India, Allahabad, India

Dr. K.A. Subramanian, Zoological Survey of India, New Alipore, Kolkata, India

Dr. P.M. Sureshan, Zoological Survey of India, Kozhikode, Kerala, India

Dr. R. Varatharajan, Manipur University, Imphal, Manipur, India

Dr. Eduard Vives, Museu de Ciències Naturals de Barcelona, Terrassa, Spain

Dr. James Young, Hong Kong Lepidopterists' Society, Hong Kong

Dr. R. Sundararaj, Institute of Wood Science \& Technology, Bengaluru, India

Dr. M. Nithyanandan, Environmental Department, La Ala Al Kuwait Real Estate. Co. K.S.C., Kuwait

Dr. Himender Bharti, Punjabi University, Punjab, India

Mr. Purnendu Roy, London, UK

Dr. Saito Motoki, The Butterfly Society of Japan, Tokyo, Japan

Dr. Sanjay Sondhi, TITLI TRUST, Kalpavriksh, Dehradun, India

Dr. Nguyen Thi Phuong Lien, Vietnam Academy of Science and Technology, Hanoi, Vietnam

Dr. Nitin Kulkarni, Tropical Research Institute, Jabalpur, India

Dr. Robin Wen Jiang Ngiam, National Parks Board, Singapore

Dr. Lional Monod, Natural History Museum of Geneva, Genève, Switzerland.

Dr. Asheesh Shivam, Nehru Gram Bharti University, Allahabad, India

Dr. Rosana Moreira da Rocha, Universidade Federal do Paraná, Curitiba, Brasil

Dr. Kurt R. Arnold, North Dakota State University, Saxony, Germany

Dr. James M. Carpenter, American Museum of Natural History, New York, USA

Dr. David M. Claborn, Missouri State University, Springfield, USA

Dr. Kareen Schnabel, Marine Biologist, Wellington, New Zealand

Dr. Amazonas Chagas Júnior, Universidade Federal de Mato Grosso, Cuiabá, Brasil

Mr. Monsoon Jyoti Gogoi, Assam University, Silchar, Assam, India

Dr. Heo Chong Chin, Universiti Teknologi MARA (UiTM), Selangor, Malaysia

Dr. R.J. Shiel, University of Adelaide, SA 5005, Australia

Dr. Siddharth Kulkarni, The George Washington University, Washington, USA

Dr. Priyadarsanan Dharma Rajan, ATREE, Bengaluru, India

Dr. Phil Alderslade, CSIRO Marine And Atmospheric Research, Hobart, Australia

Dr. John E.N. Veron, Coral Reef Research, Townsville, Australia

Dr. Daniel Whitmore, State Museum of Natural History Stuttgart, Rosenstein, Germany.

Dr. Yu-Feng Hsu, National Taiwan Normal University, Taipei City, Taiwan

Dr. Keith V. Wolfe, Antioch, California, USA

Dr. Siddharth Kulkarni, The Hormiga Lab, The George Washington University, Washington,

D.C., USA

Dr. Tomas Ditrich, Faculty of Education, University of South Bohemia in Ceske

Budejovice, Czech Republic

Dr. Mihaly Foldvari, Natural History Museum, University of Oslo, Norway

Dr. V.P. Uniyal, Wildlife Institute of India, Dehradun, Uttarakhand 248001, India

Dr. John T.D. Caleb, Zoological Survey of India, Kolkata, West Bengal, India

Dr. Priyadarsanan Dharma Rajan, Ashoka Trust for Research in Ecology and the Environment (ATREE), Royal Enclave, Bangalore, Karnataka, India

\section{Fishes}

Dr. Neelesh Dahanukar, IISER, Pune, Maharashtra, India

Dr. Topiltzin Contreras MacBeath, Universidad Autónoma del estado de Morelos, México

Dr. Heok Hee Ng, National University of Singapore, Science Drive, Singapore

Dr. Rajeev Raghavan, St. Albert's College, Kochi, Kerala, India

Dr. Robert D. Sluka, Chiltern Gateway Project, A Rocha UK, Southall, Middlesex, UK

Dr. E. Vivekanandan, Central Marine Fisheries Research Institute, Chennai, India

Dr. Davor Zanella, University of Zagreb, Zagreb, Croatia

Dr. A. Biju Kumar, University of Kerala, Thiruvananthapuram, Kerala, India

Dr. Akhilesh K.V., ICAR-Central Marine Fisheries Research Institute, Mumbai Research

Centre, Mumbai, Maharashtra, India

Dr. J.A. Johnson, Wildlife Institute of India, Dehradun, Uttarakhand, India

\section{Amphibians}

Dr. Sushil K. Dutta, Indian Institute of Science, Bengaluru, Karnataka, India

Dr. Annemarie Ohler, Muséum national d'Histoire naturelle, Paris, France

\section{Reptiles}

Dr. Gernot Vogel, Heidelberg, Germany

Dr. Raju Vyas, Vadodara, Gujarat, India

Dr. Pritpal S. Soorae, Environment Agency, Abu Dubai, UAE.

Prof. Dr. Wayne J. Fuller, Near East University, Mersin, Turkey

Prof. Chandrashekher U. Rivonker, Goa University, Taleigao Plateau, Goa. India

Dr. S.R. Ganesh, Chennai Snake Park, Chennai, Tamil Nadu, India

Dr. Himansu Sekhar Das, Terrestrial \& Marine Biodiversity, Abu Dhabi, UAE
Birds

Dr. Hem Sagar Baral, Charles Sturt University, NSW Australia

Dr. Chris Bowden, Royal Society for the Protection of Birds, Sandy, UK

Dr. Priya Davidar, Pondicherry University, Kalapet, Puducherry, India

Dr. J.W. Duckworth, IUCN SSC, Bath, UK

Dr. Rajah Jayapal, SACON, Coimbatore, Tamil Nadu, India

Dr. Rajiv S. Kalsi, M.L.N. College, Yamuna Nagar, Haryana, India

Dr. V. Santharam, Rishi Valley Education Centre, Chittoor Dt., Andhra Pradesh, India

Dr. S. Balachandran, Bombay Natural History Society, Mumbai, India

Mr. J. Praveen, Bengaluru, India

Dr. C. Srinivasulu, Osmania University, Hyderabad, India

Dr. K.S. Gopi Sundar, International Crane Foundation, Baraboo, USA

Dr. Gombobaatar Sundev, Professor of Ornithology, Ulaanbaatar, Mongolia

Prof. Reuven Yosef, International Birding \& Research Centre, Eilat, Israel

Dr. Taej Mundkur, Wetlands International, Wageningen, The Netherlands

Dr. Carol Inskipp, Bishop Auckland Co., Durham, UK

Dr. Tim Inskipp, Bishop Auckland Co, Durham, UK

Dr. V. Gokula, National College, Tiruchirappalli, Tamil Nadu, India

Dr. Arkady Lelej, Russian Academy of Sciences, Vladivostok, Russia

Dr. Simon Dowell, Science Director, Chester Zoo, UK

Dr. Mário Gabriel Santiago dos Santos, Universidade de Trás-os-Montes e Alto Douro,

Quinta de Prados, Vila Real, Portugal

Dr. Grant Connette, Smithsonian Institution, Royal, VA, USA

Dr. M. Zafar-ul Islam, Prince Saud Al Faisal Wildlife Research Center, Taif, Saudi Arabia

Mammals

Dr. Giovanni Amori, CNR - Institute of Ecosystem Studies, Rome, Italy

Dr. Anwaruddin Chowdhury, Guwahati, India

Dr. David Mallon, Zoological Society of London, UK

Dr. Shomita Mukherjee, SACON, Coimbatore, Tamil Nadu, India

Dr. Angie Appel, Wild Cat Network, Germany

Dr. P.O. Nameer, Kerala Agricultural University, Thrissur, Kerala, India

Dr. Ian Redmond, UNEP Convention on Migratory Species, Lansdown, UK

Dr. Heidi S. Riddle, Riddle's Elephant and Wildlife Sanctuary, Arkansas, USA

Dr. Karin Schwartz, George Mason University, Fairfax, Virginia.

Dr. Lala A.K. Singh, Bhubaneswar, Orissa, India

Dr. Mewa Singh, Mysore University, Mysore, India

Dr. Paul Racey, University of Exeter, Devon, UK

Dr. Honnavalli N. Kumara, SACON, Anaikatty P.O., Coimbatore, Tamil Nadu, India

Dr. Nishith Dharaiya, HNG University, Patan, Gujarat, India

Dr. Spartaco Gippoliti, Socio Onorario Società Italiana per la Storia della Fauna "Giuseppe

Altobello", Rome, Italy

Dr. Justus Joshua, Green Future Foundation, Tiruchirapalli, Tamil Nadu, India

Dr. H. Raghuram, The American College, Madurai, Tamil Nadu, India

Dr. Paul Bates, Harison Institute, Kent, UK

Dr. Jim Sanderson, Small Wild Cat Conservation Foundation, Hartford, USA

Dr. Dan Challender, University of Kent, Canterbury, UK

Dr. David Mallon, Manchester Metropolitan University, Derbyshire, UK

Dr. Brian L. Cypher, California State University-Stanislaus, Bakersfield, CA

Dr. S.S. Talmale, Zoological Survey of India, Pune, Maharashtra, India

Prof. Karan Bahadur Shah, Budhanilakantha Municipality, Kathmandu, Nepal

Dr. Susan Cheyne, Borneo Nature Foundation International, Palangkaraja, Indonesia

Dr. Hemanta Kafley, Wildlife Sciences, Tarleton State University, Texas, USA

\section{Other Disciplines}

Dr. Aniruddha Belsare, Columbia MO 65203, USA (Veterinary)

Dr. Mandar S. Paingankar, University of Pune, Pune, Maharashtra, India (Molecular)

Dr. Jack Tordoff, Critical Ecosystem Partnership Fund, Arlington, USA (Communities)

Dr. Ulrike Streicher, University of Oregon, Eugene, USA (Veterinary)

Dr. Hari Balasubramanian, EcoAdvisors, Nova Scotia, Canada (Communities)

Dr. Rayanna Hellem Santos Bezerra, Universidade Federal de Sergipe, São Cristóvão, Brazil

Dr. Jamie R. Wood, Landcare Research, Canterbury, New Zealand

Dr. Wendy Collinson-Jonker, Endangered Wildlife Trust, Gauteng, South Africa

Dr. Rajeshkumar G. Jani, Anand Agricultural University, Anand, Gujarat, India

Dr. O.N. Tiwari, Senior Scientist, ICAR-Indian Agricultural Research Institute (IARI), New

Delhi, India

Dr. L.D. Singla, Guru Angad Dev Veterinary and Animal Sciences University, Ludhiana, India

Dr. Rupika S. Rajakaruna, University of Peradeniya, Peradeniya, Sri Lanka

Dr. Bahar Baviskar, Wild-CER, Nagpur, Maharashtra 440013, India

Reviewers 2018-2020

Due to pausity of space, the list of reviewers for 2018-2020 is available online.
The opinions expressed by the authors do not reflect the views of the Journal of Threatened Taxa, Wildlife Information Liaison Development Society, Zoo Outreach Organization, or any of the partners. The journal, the publisher, the host, and the partners are not responsible for the accuracy of the political boundaries shown in the maps by the authors.

\footnotetext{
Print copies of the Journal are available at cost. Write to:

The Managing Editor, JoTT,

c/o Wildlife Information Liaison Development Society,

No. 12, Thiruvannamalai Nagar, Saravanampatti - Kalapatti Road,

Saravanampatti, Coimbatore, Tamil Nadu 641035, India

ravi@threatenedtaxa.org
} 


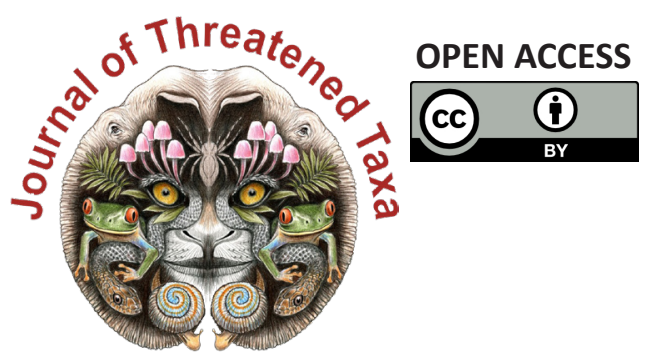

www.threatenedtaxa.org

The Journal of Threatened Taxa (JoTT) is dedicated to building evidence for conservation globally by publishing peer-reviewed articles online every month at a reasonably rapid rate at www.threatenedtaxa.org. All articles published in JoTT are registered under Creative Commons Attribution 4.0 International License unless otherwise mentioned. JoTT allows allows unrestricted use, reproduction, and distribution of articles in any medium by providing adequate credit to the author(s) and the source of publication.

\section{ISSN $0974-7907$ (Online) | ISSN $0974-7893$ (Print)}

\section{October 2021 | Vol. 13 | No. 12 | Pages: 19675-19886 \\ Date of Publication: 26 October 2021 (Online \& Print) DOI: 10.11609/jott.2021.13.12.19675-19886}

Articles

Roosting habits and habitats of the Indian Flying Fox Pteropus medius Temminck, 1825 in the northern districts of Tamil Nadu, India

- M. Pandian \& S. Suresh, Pp. 19675-19688

Diversity and distribution of avifauna at Warathenna-Hakkinda Environmental Protection Area in Kandy, Sri Lanka

- Dinelka Thilakarathne, Tithira Lakkana, Gayan Hirimuthugoda, Chaminda Wijesundara \& Shalika Kumburegama, Pp. 19689-19701

Grass species composition in tropical forest of southern India

- M. Ashokkumar, S. Swaminathan \& R. Nagarajan, Pp. 19702-19713

\section{Communications}

Habitat use and conservation threats to Wild Water Buffalo Bubalus arnee (Mammalia: Artiodactyla: Bovidae) in Koshi Tappu Wildlife Reserve, Nepal

- Reeta Khulal, Bijaya Neupane, Bijaya Dhami, Siddhartha Regmi, Ganesh Prasad Tiwari \& Manita Parajuli, Pp. 19714-19724

Get my head around owls: people perception and knowledge about owls of Andaman Islands

- Shanmugavel Sureshmarimuthu, Santhanakrishnan Babu, Nagaraj Rajeshkumar \& Honnavalli Nagaraj Kumara, Pp. 19725-19732

Abundance and diversity of threatened birds in Nangal Wetland, Punjab, India - Rajwinder Kaur \& Onkar Singh Brraich, Pp. 19733-19742

Evaluation of fish diversity and abundance in the Kabul River with comparisons between reaches above and below Kabul City, Afghanistan

- Ugyen Kelzang, Ahmad Farid Habibi \& Ryan J. Thoni, Pp. 19743-19752

New record of Myrmarachne melanocephala MacLeay, 1839 (Araneae: Salticidae) from Jharkhand, India and biogeographical implications of the co-occurrence of its ant model Tetraponera rufonigra Jerdon, 1851

- Rahul Kumar, Mirtunjay Sharma \& Ajay Kumar Sharma, Pp. 19753-19761

Diversity of spiders (Arachnida: Araneae) and the impact of pruning in Indian sandalwood plantations from Karnataka, India

-S. Padma 1 \& R. Sundararaj, Pp. 19762-19772

New records of cheilostome Bryozoa from the eastern coast of India encrusting on the exoskeleton of live horseshoe crabs of Indian Sundarbans

- Swati Das, Maria Susan Sanjay, Basudev Tripathy, C. Venkatraman \& K.A. Subramanian, Pp. 19773-19780

On the pteridophytes of Bherjan-Borajan-Padumoni Wildlife Sanctuary, Assam, India - Pranjal Borah \& Jayanta Barukial, Pp. 19781-19790

Population status of Heritiera fomes Buch.-Ham., a threatened species from Mahanadi Mangrove Wetland, India

- Sudam Charan Sahu, Manas Ranjan Mohanta \& N.H. Ravindranath, Pp. 19791-19798

Additions to the lichenized and lichenicolous fungi of Jammu \& Kashmir from Kishtwar High Altitude National Park

- Vishal Kumar, Yash Pal Sharma, Siljo Joseph, Roshinikumar Ngangom \& Sanjeeva Nayaka, Pp. 19799-19807

\section{Short Communications}

Is release of rehabilitated wildlife with embedded lead ammunition advisable? Plumbism in a Jaguar Panthera Onca (Mammalia: Carnivora: Felidae), survivor of gunshot wounds - Eduardo A. Díaz, Carolina Sáenz, E. Santiago Jiménez, David A. Egas \& Kelly Swing, Pp. 19808-19812

New record of the Sewing Needle Zipper Loach Paracanthocobitis linypha Singer \& Page, 2015 (Teleostei: Cypriniformes: Nemacheilidae) from the Chindwin drainage of Manipur, India

- Yumnam Rameshori, Yengkhom Chinglemba \& Waikhom Vishwanath, Pp. 19813-19817

Field identification characters to diagnose Microhyla mukhlesuri from closely related M. mymensinghensis (Amphibia: Microhylidae) and range extension of $M$. mukhlesuri up to West Bengal State, India

- Suman Pratihar \& Kaushik Deuti, Pp. 19818-19823
First report of Scipinia horrida (Stål) (Heteroptera: Reduviidae) from Assam, with comments on related genus Irantha Stål

- Anjana Singha Naorem, Santana Saikia, Anandita Buragohain, Rubina Azmeera Begum, Swapnil S. Boyane \& Hemant V. Ghate, Pp. 19824-19830

Flesh fly (Diptera: Sarcophagidae): male terminalia, diversity and expanded geographical distribution from India

- Kanholi Sreejith, Shuvra Kanti Sinha, Santanu Mahato \& Edamana Pushpalatha, Pp. 1983119836

Checklist of moths (Heterocera) of Tadong, Sikkim, India

- Prayash Chettri, Yuki Matsui, Hideshi Naka \& Archana Tiwari, Pp. 19837-19848

New distribution records of Begonia L., B. murina Craib and B. poilanei Kiew (Begoniaceae: Cucurbitales) for Laos

- Phongphayboun Phonepaseuth, Phetlasy Souladeth, Soulivanh Lanorsavanh, Shuichiro Tagane, Thyraphon Vongthavone \& Keooudone Souvannakhoummane Pp. 19849-19854

Notes

A recent sighting of the Stripe-backed Weasel Mustela strigidorsa (Mammalia: Carnivora: Mustelidae) in Hkakabo Razi Landscape, Myanmar

- Sai Sein Lin Oo, Tun Tun, Kyaw Myo Naing \& Paul Jeremy James Bates, Pp. 19855-19859

Are the uplifted reef beds in North Andaman letting nesting Olive Ridley Sea Turtle Lepidochelys olivacea stranded?

- Nehru Prabakaran, Anoop Raj Singh \& Vedagiri Thirumurugan, Pp. 19860-19863

First record of the orb-weaving spider Araneus tubabdominus Zhu \& Zhang, 1993 (Araneae: Araneidae) from India

- Souvik Sen, John T.D. Caleb \& Shelley Acharya, Pp. 19864-19866

The genus Catapiestus Perty, 1831 (Coleoptera: Tenebrionidae: Cnodalonini) from Arunachal Pradesh with one new record to India

- V.D. Hegde \& Sarita Yadav, Pp. 19867-19869

Rediscovery and extended distribution of Indigofera santapaui Sanjappa (Leguminosae: Papilionoideae) from the states of Maharashtra and Gujarat, India

- Kumar Vinod Chhotupuri Gosavi, Sanjay Gajanan Auti, Sharad Suresh Kambale \& Munivenkatappa Sanjappa, Pp. 19870-19873

Additional distribution records of Ceropegia anjanerica, an endemic and 'Endangered' lantern flower of the northern Western Ghats, India

- Samir Shrikant Maity, Ajay Natha Gangurde, Sharad Suresh Kambale, Avinash Ramchandra Gholave, Avinash Asraji Adsul, Ganesh Babaso Pawar \& Kumar Vinod Chhotupuri Gosavi, Pp. 19874-19877

Notes on the extended distribution of Impatiens megamalayana, a recently described balsam in Western Ghats, India

- Anoop P. Balan \& A.J. Robi, Pp. 19878-19883

Book Review

A look over on the scented tree of India (Santalum album - S. Suresh Ramanan \& A. Arunachalam, Pp. 19884-19886
Publisher \& Host
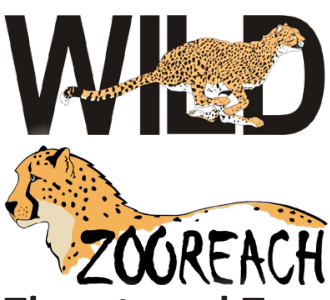

Threatened Taxa 